\title{
FACTORS AFFECTING INFANT MORTALITY RATE IN KARANGASEM, BALI
}

\author{
Ni Luh Putu Suciptawati, Made Asih, Kartika Sari, I G A M Srinadi
}

Department of Mathematics FMIPA Udayana University, Bukit Jimbaran, Indonesia

\section{ARTICLE INFO}

Article history:

Received: 1 August 2018

Received in revised form: 10 October 2018

Accepted: 10 January 2019

Keywords:

infant mortality

infant weight

Log linier model

\begin{abstract}
A B S T R A C T
The purpose of this study was to determine the factors that influence the infant mortality rate in Karangasem, Bali. The method used in this research is the Log Linier model. In the Log linear model analyze relationship pattern among group of categorical variables which include an association of two or more variables, either simultaneously or partially. A Patterned relationship between variables can be seen from the interaction between variables. Log linear analysis does not distinguish between explanatory variables and response variables. The population in this study was all babies born in Karangasem in 2015 that is as many as 7,895 babies with live birth status and as many as 7,835 babies and 60 infants died. As a sample, 100 babies were taken, of which 60 were live and 40 died. The results show that infant mortality is affected by infant weight, how old the mother during childbirth, and interaction between birth spacing and infant weight.
\end{abstract}

(C) 2018 IJPNA. All rights reserved.

\section{INTRODUCTION}

Health degree is one measure of welfare and human resources. The Infant Mortality Rate (IMR) is an indicator commonly used to determine public health status, IMR is calculated based on the number of babies who died in the phase between birth to infant and has not reached the age of 1 year per 1,000 live births. World Health Organization (WHO) states in 2015 Noted there were 70,000 infants in Indonesia who died in the first 28 days of life, equivalent to 22 per 1,000 live births.

According to (Dinas Kesehatan Provinsi Bali, 2016), infant mortality rate in Bali by 2015 is lower than the average infant mortality rate nationally. The highest infant mortality rate in Karangasem regency was 10.6 / 1000 live births, while the lowest was in Denpasar at $0.6 / 1000$. One of the causes of infant mortality in Bali is law dirth weight infants (LDWI) and asphyxia.

According to (Sukamdi, 1995) there are four factors related to infant mortality, (i.e. socio-economic factors, cultural factors, health factors, and demographic factors). Socioeconomic factors explain that the income, education, and participation of the female labor force influence the infant mortality rate. Cultural factors explain the relationship between ethnicity, religion, sex selection of children against infant mortality rate. Health development has a negative relationship with infant mortality rate, meaning that if the infant mortality rate is high, health development has not been successful. The variables that can be included in the health indicators include the ratio of health personnel, such as doctors, nurses, and midwives to the population.

To see the cause of infant mortality, this study uses five factors: Age of childbirth, birth spacing, birth order, mother's education, and weight of infants. To know the factors that influence the cause of infant mortality in Karangasem regency we use a log-linear model. The log-linear model is a model that represents the relationship between two or more variables in which all variables are categorical and the validity of the models is tested by the contingency table approach (Agresti 2007)

*E-mail: suciptawati@unud.ac.id 
Volume 4, Number 1, February 2019, p. 12-15

e-ISSN 2550-0570, C FSM UKSW Publication

Table 1. Material composition for ORIGEN2.1 inputs

\begin{tabular}{ccc}
\hline No & Isotope & Composition (grams) \\
\hline 1 & U-234 & 0.84953 \\
2 & $\mathrm{U}-235$ & 0.84953 \\
3 & $\mathrm{U}-238$ & 4.14618 \\
4 & $\mathrm{O}-16$ & 0.67334 \\
5 & $\mathrm{C}-12$ & 195.6738 \\
6 & $\mathrm{Si}-28$ & 1.28956 \\
\hline
\end{tabular}

\section{METHODOLOGY}

The population of the study is the number of babies born in Karangasem Regency during 2015. The data obtained on the number of babies born was as many as 7,895 babies with live birth status and as many as 7,835 , born alive 7,835 and 60 dead babies. The response variable (Y) in this research is infant status, while the independent variable consisted of: Age of childbirth was grouped into 3 classifications (ie: age $<20$ years, age $20-35$ years, and age $>35$ years), birth spacing was grouped into 3 classifications (ie: $<2$ years, $2-5$ years, and $>5$ years), birth order was grouped into 3 classifications (ie: first, 2nd-4th, and $>4$ th), Mother's education level was grouped into 3 classifications (ie:primary school, Junior high school, and $>$ or $=$ Senior High School, and infant's weight was grouped into 3 classifications (ie: $<2.5 \mathrm{~kg}, 2.5-4 \mathrm{~kg}$, and $>4$ $\mathrm{kg})$.

The proportion of live and dead infants is unbalanced, so to obtain a sufficient number of samples in the study, it used the sampling with a certain consideration (purposive sampling). The considerations taken are to take 60 live babies and 40 babies die randomly as members of the sample. The data obtained was analyzed using the Log Linear model. In general, the saturated model containing all possible parameters of the research variables is stated as follows: (Christensen 1997)

$$
\begin{aligned}
& \log m_{Y X_{1} X_{2} X_{3} X_{4} X_{5}}= \\
& U+U_{1(Y)}+U_{2\left(X_{1}\right)}+U_{3\left(X_{2}\right)}+ \\
& U_{4\left(X_{3}\right)}+U_{5\left(X_{4}\right)}+U_{6\left(X_{5}\right)}+U_{12\left(Y X_{1}\right)}+ \\
& \ldots+U_{16\left(Y X_{5}\right)}+U_{23\left(X_{1} X_{2}\right)}+U_{24\left(X_{1} X_{3}\right)}+ \\
& \ldots+U_{123\left(Y X_{1} X_{2}\right)}+\ldots+U_{123456\left(Y X_{1} X_{2} X_{3} X_{4} X_{5}\right)}
\end{aligned}
$$

1) Where

$$
U_{1(Y)}=\text { infant status, } U_{2\left(X_{1}\right)}=\text { Age of }
$$

childbirth, $U_{3\left(X_{2}\right)}=$ birth spacing,$U_{4\left(X_{3}\right)}=$ birth order, $U_{5\left(X_{4}\right)}=$ Mother's education, $U_{6\left(X_{5}\right)}=$ infant weight $U_{12\left(Y X_{1}\right)}$, the interaction effect between frequency $U_{1(Y)}$ and $U_{2\left(X_{1}\right)}, \ldots$.

Furthermore, based on the saturated model formed the best model is obtained by using the backward elimination method. The basic rule of backward elemination is used by entering the saturated model, The basic rule of backward elemination is to insert the saturated model and then set aside one by one until it has a simple model. If the model obtained is known to be a relationship or non-freedom, then the next step is to find the source of freedom by looking at the value of standardized residuals.

\section{RESULTS AND DISCUSSION}

\begin{tabular}{|c|c|c|c|c|c|}
\hline & \multirow[t]{2}{*}{ District } & \multirow[t]{2}{*}{ PUSKESMAS } & \multicolumn{3}{|c|}{ Number of Infants } \\
\hline & & & Live & Die & Live+Die \\
\hline 1 & Manggis & Manggis I & 512 & 5 & 517 \\
\hline & & Manggis II & 231 & 0 & 231 \\
\hline 2 & Sidemen & Sidemen & 589 & 3 & 592 \\
\hline 3 & Selat & Selat & 618 & 4 & 622 \\
\hline
\end{tabular}

The number of infants in each Puskesmas in Karangasem regency is presented in table 1 below: 2015

Table 1.The Number of Infants at District and Puskesmas in Karangasem Regency in Year 


\begin{tabular}{|c|c|c|c|c|c|}
\hline 4 & Rendang & Rendang & 598 & 6 & 604 \\
\hline 5 & Bebandem & Bebandem & 811 & 5 & 816 \\
\hline \multirow[t]{2}{*}{6} & Karangasem & Karangasem I & 1.258 & 5 & 1.263 \\
\hline & & Karangasem II & 527 & 7 & 534 \\
\hline \multirow[t]{2}{*}{7} & Abang & Abang I & 659 & 5 & 664 \\
\hline & & Abang II & 673 & 8 & 681 \\
\hline \multirow[t]{2}{*}{8} & Kubu & Kubu I & 455 & 4 & 459 \\
\hline & & Kubu II & 904 & 8 & 912 \\
\hline \multicolumn{2}{|c|}{ Total(Regency) } & & 7,835 & 60 & 7,895 \\
\hline
\end{tabular}

Source: Profil Kesehatan Kabupaten Karangasem (2016)

It appears that in 2015 in Puskesmas Manggis only 2 did not find the case of infant mortality, while other Puskesmas still found cases of infant mortality.

Table 2. Infant Status on Each RespondenceDemograpics Caracteristics.

\begin{tabular}{|l|l|l|l|}
\hline $\begin{array}{l}\text { Characteristics } \\
\text { of Respondents }\end{array}$ & \multicolumn{2}{|c|}{ Birth Status } & Total \\
\cline { 2 - 3 } & Die & Live & \\
\hline $\begin{array}{l}\text { Age of } \\
\text { childbirth } \\
\text { a. }<20 \text { years } \\
\text { b. } 20-35 \text { years }\end{array}$ & 17 & 2 & 16 \\
c. $>35$ years & 13 & 51 & 61 \\
\hline $\begin{array}{l}\text { Birth spacing } \\
\text { a. }<2 \text { years } \\
\text { b.2-5 years } \\
\text { c. }>5 \text { years }\end{array}$ & 20 & 25 & 23 \\
\hline $\begin{array}{l}\text { Birth Order } \\
\text { a. First } \\
\text { b. } 2 \text { nd }-4^{\text {th }}\end{array}$ & 13 & 32 & 39 \\
c. $>4^{\text {th }}$ & 16 & 39 & 16 \\
\hline $\begin{array}{l}\text { Mother's } \\
\text { education } \\
\text { a. primary } \\
\text { school } \\
\text { b. Junior high } \\
\text { school } \\
\text { c. }>=\text { Senior high } \\
\text { school }\end{array}$ & 5 & 37 & 42 \\
\hline
\end{tabular}

\begin{tabular}{|l|l|l|l|}
\hline Infant Weight & & & \\
a. $<2.5 \mathrm{~kg}$ & 27 & 8 & 35 \\
b. $2.5-4 \mathrm{~kg}$ & 6 & 43 & 49 \\
c. $>4 \mathrm{~kg}$ & 7 & 9 & 16 \\
\hline
\end{tabular}

Source: Data processed (2016)

Descriptively, it appears that most infant deaths occur when there is a low birth weight in infants (LDWI). According to (Depkes, 2004) in (Pramono M.S. dan G. Putro 2009) $57 \%$ of infant deaths are caused by impairment during prenatal frequency funds and LDWI. LDWI can occur when Age of childbirth $<20$ years, and mother's education was low.

Results: Analysis by using Loglinier model obtained the following results:

1. There is a correlation between the frequency of the birth status of the infant and the Age of childbirth at each frequency level of birth order, the birth spacing, the mother's education, and infant weight.

2. There is a correlation between the frequency of infant status, at each Age of childbirth, birth order, the mother's education, and infant weight.

3. There is a correlation between the frequency of infant status with the mother's education, at each age level of childbirth, birth order, birth spacing, and infant weight.

Factors that affect infant mortality can be seen from factors that interact with the birth status of the infant.

There is an interaction between the infant status and the age of childbirth, meaning that 
Volume 4, Number 1, February 2019, p. 12-15

e-ISSN 2550-0570, C FSM UKSW Publication

the age of childbirth affects infant mortality. It can be seen from table 2 that the frequency of infant deaths is highest at age of childbirth $<20$ years. This is in accordance with the fact that at that age growth and development of the pelvic cavity is not optimal, so it will complicate the mother in the process of childbirth (Maryatun 2010).

There is an interaction between infant status and infant weight, as revealed (Pramono M.S. and G. Putro, 2009) LDWI can result in infant mortality if not handled appropriately. Infant mortality is affected by the interaction between birth spacing and infant birth weight. Another factor that affects infant mortality is the interaction between birth spacing and infant weight, as well as the interaction between birth order and maternal education.

Results should be clear and concise. Discussion should explore the significance of the results of the work, not repeat them. A combined Results and Discussion section is often appropriate. Avoid extensive citations and discussion of published literature.

Table 1. Geometric data of AP1000.

\begin{tabular}{cll}
\hline No. & Parameter & Nilai \\
\hline 1 & Volume of ruang sungkup $\left(\mathrm{m}^{3}\right)$ & 58300 \\
2 & Water Volume IRWST $\left(\mathrm{m}^{3}\right)$ & 2100 \\
3 & Water Volume PCCWST $\left(\mathrm{m}^{3}\right)$ & 3000 \\
4 & Water Volume 2 CMT $\left(\mathrm{m}^{3}\right)$ & 140 \\
5 & Wall thcikness of sungkup (m) & 0,0444 \\
6 & Height of sungkup (m) & 65,634 \\
7 & Diameter of sungkup dalam (m) & 39,624 \\
\hline
\end{tabular}

\section{CONCLUSION}

The variables that affect infant mortality in Karangasem regency are Age of childbirth and infant weight. While the order of birth and birthspacing has no direct effect on infant mortality, infant weight is influential.

\section{Suggestion}

To reduce the infant mortality rate, the related institutions can provide education to the citizens not to get married and not to get pregnant at a young age. There needs to be counseling to pregnant women about sufficient nutrient intake so as to avoid giving birth to and infant with LDWI.

\section{ACKNOWLEDGMENT}

Acknowledgment is recommended to be given to persons or organizations helping the authors in many ways. Sponsor and financial support acknowledgments may be placed in this section. Use the singular heading even if you have many acknowledgments.

\section{REFERENCES}

Agresti, Alan. An Introduction to Categorical Data Analysis Second Edition. New Jersey: John Wiley \& Sons, Inc, 2007.

Dinas kesehatan Provinsi Bali. Profil Kesehatan Provinsi Bali Tahun 2015. April 1, 2016. (accessed Oktober 20, 2016).

Christensen, R. Log Linear Model and Logistic Regression. . New York: Springer-Verlag, Inc, 1997.

Maryatun. "Bahaya Kehamilan Pada Perkawinan Usia Muda." Jurnal Ilmiah Rekam medis dan Informatika Kesehatan, 2010: 74-82.

Pramono M.S. dan G. Putro. "Resiko terjadinya Berat Bayi Rendah Menurut Determinasi Sosial, Ekonomi dan Demografi dari Indonesia." Buletin Penelitian Sistem Kesehatan, 2009: 127-132. 